Article

\title{
On the Origin and Conceptual Development of 'Essence-Function' (ti-yong)
}

\author{
Sun-hyang Kwon ${ }^{1}$ and Jeson Woo ${ }^{2, *}$ \\ 1 Department of Education, Korea University, 145 Anam-ro, Seongbuk-gu, Seoul 02841, Korea; \\ teresarang@gmail.com \\ 2 Department of Buddhist Studies, Dongguk University, 30, 1 gil Phildong-ro, Joong-gu, Seoul 04620, Korea \\ * Correspondence: jwoo@dongguk.edu
}

Received: 12 March 2019; Accepted: 11 April 2019; Published: 16 April 2019

check for updates

\begin{abstract}
Essence-function' (ti-yong 體用), also called 'substance-function,' has been a constant topic of debate in monastic and academic communities in China. One group of scholars insists that the concept is derived from the Confucian tradition, while the other maintains that it originates with the Buddhist tradition. These opposing opinions are not merely the arguments of antiquity, but have persisted to our present time. This paper investigates the concept of 'essence-function,' focusing on its origin and conceptual development in the Buddhist and the Confucian traditions. This concept has become a basic framework of Chinese religions. Its root appears already in ancient Confucian and Daoist works such as the Xunzi and the Zhouyi cantong qi. It is, however, through the influence of Buddhism that 'essence' and 'function' became a paradigm used as an exegetical, hermeneutical and syncretic tool for interpreting Chinese philosophical works. This dual concept played a central role not only in the assimilation of Indian Buddhism in China during its earlier phases but also in the formation of Neo-Confucianism in medieval times. This paper shows that the paradigm constituted by 'essence' and 'function' resulted not from the doctrinal conflicts between Confucianism and Buddhism but from the interactions between them.
\end{abstract}

Keywords: essence-function; principle-phenomena; principle-vital force; ti-yong; li-shi; li-qi

\section{Introduction}

The 'essence-function' (ti-yong 體用 $)^{1}$ is a core concept in Chinese philosophy. It serves as the basic philosophical framework for all major Chinese religions. This dual concept became the foundation of the 'principle and vital force' (li-qi 理氣) which is the defining characteristic of Neo-Confucianism. It was also the primary paradigm for the development of Buddhism in China, which distinguishes Chinese Buddhism from Indian Buddhism. Since the concept of 'essence-function' played a central role in the thought systems of both Confucianism and Chinese Buddhism, an issue has been debated concerning whether it is an exclusively Sinitic element or not. The disagreement among scholars was

1 The term $t i$ 體 can mean 'body,' 'entity,' 'substance,' 'essence,' 'system,' etc. As Charles Muller explains, its English translation is problematic. Its problematic character derives generally from the fact that Western religious and philosophical discourses are traditionally more dualistic than Eastern (Muller 2016, pp. 124-26). Following the practice of Muller and other scholars, in this paper we have chosen the English word 'essence' over other alternatives. 
over its exact origin. Confucianists regarded this concept as intrinsic to Chinese indigenous religions, while Buddhists asserted that it owes its essential features to the influence of Buddhism.

The argument on the origin of 'essence-function' emerged in the Southern Song dynasty (1127-1279) and came to a head during the period of transition between the Ming 明 (1368-1644) and the Qing 清 (1636-1912) dynasties. Two important philosophers, Li Yong 李顒 (1613-1682) and Gu Yanwu 顧炎武 (1627-1705), extensively debated on the concept of 'essence-function.' Gu Yanwu insisted that it was already an element of pre-Chin Confucianism. To demonstrate this, he attributed its origin to the Zhouyi cantong q $i$ 周易參同契 by Wei Boyang 魏伯陽, ${ }^{2}$ which contains the concepts of both 'essence' and 'function.' On the other hand, Li Yong argued that 'essence' and 'function' in that text denote something other than the commonly understood 'essence-function.' He maintained that the dual concept was first formulated by the eminent Chan master, Huineng 慧能 (638-713). It is clear that the debate between Gu Yanwu and Li Yong over this concept reverberated throughout since then, suggesting important implications regarding its origin.

The debate on the concept of 'essence-function' continues in modern East Asian scholarship. In modern scholarship, however, the heated debate surrounding its origin has shifted, as the focus is now on investigating how this concept was employed in the doctrinal structures of various strands of Buddhism and Confucianism when it was theoretically developed in each religious tradition. This scholarly controversy is closely related to its key role in their thought systems. Our inquiry emphasizes Confucian-Buddhist interactions over their individual facets when dealing with the origin and conceptual development of 'essence and function.' This dual concept has been the most widely used hermeneutic framework employed in the interpretation of religious and philosophical works in China up to premodern times. ${ }^{3}$ For this reason, the present investigation will demonstrate that the conceptual development of 'essence-function' was based on the interreligious dialogues between Confucianism and Buddhism.

\section{The Origin in Chinese Indigenous Religions}

'Essence’ ( $t i$ 體) is the fundamental basis or origin of something, whereas 'function' (yong 用) refers to phenomena that are concretely manifested by 'essence.' These terms appear in Chinese literature as early as the pre-Qin period (770-221 BCE). ${ }^{4}$ It is worth noting, however, that the concepts of 'essence' and 'function' are barely recorded in the literature of this period. The appearance of the concepts was first advanced in the Xunzi 荀子, which argued as follows:

Although many things co-exist in the same space, they are composed of different 'essences' and have no predetermined 'functions.' However, each human has many potential 'functions.' 5

The Xunzi describes entities in the phenomenal world using the terms 'essence' and 'function,' and proposes that 'essence' is a compositional principle of a thing and 'function' is a quality that

2 Wei Boyang' s Zhouyi cantong qi was written in the East Han 東漢 dynasty. It was the first book of alchemy in the world, and is thus recognized as a foundational text of ancient Chinese alchemy. It is worth noting that Wei Boyang was a contemporary of Emperor Huandi 桓帝 (147-167).

See (Muller 2016), p. 113.

See (Ryden 2002), pp. 241-42.

5 Xunzi 10: “萬物同宇 而異體無宜而有用為人數也.” Recited from (Knoblock 1988), p. 120. 
is potentially possessed by a human being. Even though both terms appear together in the text, it is not clear whether or not there is a mutual relationship between them. ${ }^{6}$

$\mathrm{Gu}$ Yanwu observes that the concepts of 'essence' and 'function' originally appeared in the Zhouyi cantong qi by Wei Boyang in the Lianghan 兩漢 period (206 BCE-220). This text contains the following observation:

Spring and summer are based on inner 'essence,' and autumn and winter are based on outer 'function'?

There is an ongoing argument about whether the 'essence' and the 'function' alluded to in this text are mere philosophical abstractions or just refer to concrete particularities in the physical world. Yet, Wei Boyang' s use of the terms reflects a simple tenet of Confucianism, as exemplified by the concept of yin-yang 陰陽, which represents the principle of complementarity in ancient Chinese philosophy describing how seemingly opposite or contrary forces interrelate to each other.

The concept of 'essence-function' was first used as a philosophical paradigm during the Weijin Nanbeichao 魏晉南北朝 dynasty (220-589)—the period in which Wang Bi 王貆 (226-249) engaged his academic pursuits. Today, many researchers consider his thought on Xuanxue 玄學, a branch of Daoism, as a forerunner of the concept of 'essence and function' in Neo-Confucianism. They maintain that Wang Bi' s use of the notion of 'root and stem' was a paradigmatic shift in the evolution of this dual concept. According to Wang Bi, 'existence' (you 有) stems from 'nonexistence' (wu 無). ${ }^{8}$ This nonexistence can be understood as the predecessor of the concept of 'essence.' In his theory, each phenomenon has a 'function' caused by this essential root. ${ }^{9}$

Wang Bi' s idea of nonexistence is analogous to the Buddhist notion of emptiness (kong 空) proposed by the Prajña $\bar{a}$ school, in the sense that both concepts refer to the intrinsic nature of all things. As a matter of fact, Wang Bi' s concept of nonexistence cannot be explained without the notion of emptiness. This is why Wang Xiaoyi 王曉毅 and Lu Cheng 呂澂 considered that Wang Bi was influenced by Buddhism. ${ }^{10}$ It is sufficiently clear that Wang Bi lived before the emergence of Chinese Buddhism in the $4^{\text {th }}$ to $5^{\text {th }}$ century; yet, this fact notwithstanding, there is a possibility that he encountered a certain type of Buddhism because his academic activities coincided with the period of the transmission and assimilation of Indian Buddhism in China during its earliest phases. ${ }^{11}$ Moreover, Wang Bi' s ontology includes drastic changes that are not found in the Laozi 老子 and the Book of Changes (周易). ${ }^{12}$

6 For a detailed interpretation of the Xunzi 10, see (Zhang 1996), pp. 241-42.

7 (ZhS) 119,c6-7: “春夏據內體 從子到辰巳 秋冬當外用 自午訖戌亥.”

8 Note (CLD) 164,b15-165,a1: 萬物萬形其歸一也 何由致一由於無也 由無乃一一可謂無 已謂之一豈得無言乎有言有一非二 如何 有一有二 遂生乎三從無之有 數盡乎斯.

9 See (CLD) 161,b6-7: 萬物雖貴 以無爲用.

10 For details on the Buddhist influence on Daoists such as Wang Bi, see (Wang 1993, pp. 207-17; Lim 1997, pp. 113-32; Lu 1979, p. 33ff). Wang Bi' s identification of nonexistence and 'function' is similar to the Buddhist conception of the relationship between emptiness and 'function.' Unlike Buddhism, which posits a development coextensive with the dual concept of 'essence' and 'function,' however, his perspective does not have a complementary character.

11 With regard to the transmission and assimilation of Buddhism from India to China, see (Mair 2012), pp. 32-55.

12 For the earliest precursors of the concept of 'essence-function' in classical Chinese texts, such as the Book of Changes, see also (Muller 1999). 


\section{The Origin in Buddhism}

As discussed above, Li Yong maintained that the concept of 'essence-function' was first framed by Huineng in the $7^{\text {th }}$ century. However, Sengzhao 僧肇 (384-414), a disciple of the eminent Buddhist translator Kumrajīva, had already employed it in the $4^{\text {th }}$ century. One of the most notable achievements of Sengzhao was to re-envision the theory of twofold truth (erdishuo 二諦說) through the prism of Chinese philosophy. ${ }^{13}$ He understood the twofold truth, comprised of 'ultimate truth' (zhendi 眞諦) and 'conventional truth' (sudi 俗諦), in terms of the concepts of 'essence' and 'function,' asserting that the two are inseparable. He compared 'essence and function' to 'stillness and movement.' This can be found in the following description:

Even though it goes, it doesn' $t$ move; it is always still. Even though it is still, it is not stationary; it is always moving. It is still, but it always goes. Because of this, it doesn' $t$ move as it goes. Even though it is moving, it is always still. It is still, but it isn' t stationary. ${ }^{14}$

This passage explains that a body moves while being still and is static as it moves. Such a state of stillness and movement is called xiangji 相師, a concept which denotes that two phenomena are mutually identical. From the perspective of 'conventional truth,' stillness is different from movement. From the perspective of ' ultimate truth,' on the other hand, stillness is identical to movement. They are simply different names for the same phenomenon. ${ }^{15}$ Sengzhao demonstrated that 'essence' and 'function' are also in the relationship of mutual identity (xiangji), arguing that 'essence' is in fact 'function,' and 'function' is 'essence.' In this way, this thought of mutual identity supersedes extreme views such as that "there is only 'function,' and no 'essence,'” and conversely that "there is only 'essence,' and no 'function.'”

\section{The Conceptual Development in Buddhism}

Sengzhao' s thought that 'essence' and 'function' are mutually identical was further developed in the Awakening of Mahyna Faith (大乘起信論, hereafter referred to as AMF). This text configures 'essence' and 'function' in the following dialectic: There is 'one mind,' and there are the two aspects of this 'one mind.' 16 The mind in terms of 'suchness' (zhenru 眞如) is explained as 'essence;' the mind in terms of 'phenomena' (shengmie 生滅) is described as 'function.' AMF indicates that 'essence' and 'function' have an identical origin, i.e., 'one mind.' Thus, they are by nature the

13 For Sengzhao' s understanding of the twofold truth, see (ZhL) 154,b26-c10: 難曰 聖智之無 惑智之無 俱無生滅 何以異之. 答曰 聖智之無者 無知 惑智之無者 知無 其無雖同 所以無者異也. 何者夫聖心虛靜無知可無 可曰無知非謂知無 惑智有知 故 有知可無 可謂知無 非曰無知也. 無知 即般若之無也. 知無 即真諦之無也. 是以般若之與真諦 言用即同而異 言寂即異而同 同 故無心於彼此 異故不失於照功 是以辨同者同於異 辨異者異於同 斯則不可得而異 不可得而同也. 何者 內有獨鑒之明外有萬 法之實 萬法雖實 然非照不得 內外相與以成其照功 此則聖所不能同 用也. 內雖照而無知 外雖實而無相 內外寂然相與俱無 此 則聖所不能異 寂也. For more, see (Garfield 2002), p. 91ff.

14 (ZhL) 151,b19-21: “稱去而不遷不遷故雖往而常靜不住故雖靜而常往 雖靜而常往故往而弗遷 雖往而常靜 故靜而弗留矣.”

15 (ZhL) 45,152a-b: 難曰 論云 言用則異 言寂則同 未詳般若之內 則有用寂之異乎 答曰 用即寂 寂即用 用寂體一同出而異名. See also (Tang 2002), p. 250.

16 AMF proposes the framework of one mind (一心), the two aspects (二門) of the one mind, and the three types of greatness (三大) inherent in the one mind. The mind in terms of suchness constitutes the greatness of 'essence,' while the mind in terms of phenomena represents the greatness of potentialities and the greatness of 'function.' Here, the first part of the trinity corresponds to 'essence' while the second and the third correspond to 'function.' In fact, the concept of the three types of greatness inherent in the one mind is a transitional notion that describes the process of development of ‘essence-function.’ Note also (AMF) 575,c23-25: 是心真如相 即示摩訶衍體故 是心生滅因緣相 能示摩訶衍自體相用故. For more on the concept of 'essence-function' in AMF, see (Muller 2016), pp. 131-33. 
same, but differ only in their aspect. ${ }^{17}$ This idea was advanced through Sengzhao' s proposal that 'essence' and 'function' are identical.

The focus of what is now called Huayan 華嚴 emphasized the identity of 'essence' and 'function.' Fazang 法藏 (643-712), who was in fact the progenitor of Huayan, ${ }^{18}$ systematized his thoughts on the basis of the concept of 'essence-function.' According to him, 'essence,' which manifests itself independently, is nothing other than 'function.' ${ }^{19}$ Therefore, 'essence' and 'function' in themselves are the world of truth (fajie 法界). Fazang further conceptualized 'essence' and 'function' in the context of the relationship between 'principle' ( $l i$ 理) and 'phenomena' ( $s h i$ 事), which later became one of the core terms of Neo-Confucianism. 'Principle' is the fundamental law, general pattern, or innate quality that governs reality. On the other hand, 'phenomena' are events or entities as they are experienced in the empirical world. 'Phenomena' are always changing and merging together, and as a totality form a 'principle,' as if hundreds of streams were running into the sea. According to Fazang, 'principle' is 'essence' and 'phenomena' are 'function.' To be sure, 'essence' as 'principle' has the same flavor (yiwei 一味), but it is always associated with 'function' as 'phenomena.' ${ }^{20}$ Each and every individual 'phenomenon' is pervaded by 'principle.' Thus, all the various discrete 'phenomena' in the universe are in interaction with every other ' phenomena' on the basis of 'essence.'

Chengguan 澄觀 (738-839), the fourth patriarch of the Huayan school, developed Fazang' s idea of 'essence-function' as 'principle-phenomena' one step further. According to him, the world of truth embraces 'principle' and 'phenomena' as a collective whole; so they cannot impede one another. The concept of 'dependent origination' (yuanqi 緣起), a key principle in Buddhism which stipulates that all phenomena arise in dependence upon other phenomena, refers to the myriad 'functions' of 'essence.' ${ }^{21}$ In his commentary on the Avatamsaka Sütra, Chengguan suggested as follows:

Movement and stillness are inseparable and originate from one and the same root. ${ }^{22}$

In this passage, Chengguan clarifies that movement and stillness derive from one and the same root (yiyuan 一源). Elaboration of this idea can be found in his other work, Dafangguangfo huayanjing suishu yanyi chao 大方廣佛華嚴經隨疏演義鈔. In this text, Chengguan explained that the relationship between movement and stillness is identical to that between 'phenomena' and 'principle.' Just as movement and stillness originate from one and the same root, so too do 'phenomena' and 'principle.' Chengguan maintained that this one and the same root is the 'essence' of the world

17 According to Sung-bae Park, AMF employs the concept of 'essence-function' to express the nondualistic and nondiscriminatory nature of enlightenment. See (Park 1983), p. 147.

18 See (Cook 1997), p. 32.

19 The aforementioned $\mathrm{Lu}$ Cheng points out that Fazang dealt with 'essence-function' from the perspective of various strands of Huayan studies. Note (HY) 632,b12-20: 通性起者謂塵體空無所有 相無不盡 唯一眞性 以空不守自性 即全體而成 諸法也. 是故而有萬像繁興 萬像繁興而恒不失真體一味 起恒不起 不起恒起 良以不起即起 起乃顯於緣生 起即不起 不起乃彰 於法界. 是故此塵即理即事即滅即生 皆由不起而起也 此塵亦空理亦壞亦隱 由起而不起 是故終日繁興而無施設也. For more on 'essence-function' in the context of Fazang' s thought, see (Lu 1996), pp. 27-41.

20 Note (HY) 635,a4-9: 事雖宛然 恒無所有 是故用即體也. 如會百川以歸於海 理雖一味 恒自隨緣 是故體即用也. 如舉大海以明 百川 由理事互融故體用自在 若相入則用開差別 若相即乃體恒一味 恒一恒二 是為體用也.

21 Note (DJ) 702,a7-9: 法界者是總相也. 包事包理及無障礙皆可軌持具於性分. 緣起者稱體之大用也. See also (Hamar 1998), pp. 2-3.

22 (DH) 503,a6: “往復無際 動靜一源.” 
of truth. ${ }^{23}$ Since this world empirically unfolds through the diverse 'functions' of 'essence,' the mind of living beings is able to perceive 'principle' within 'phenomena,' just as it can perceive stillness within movement. This relationship between stillness and movement is a forerunner of the Neo-Confucian conception that 'essence' and 'function' originate from one and the same root.

\section{The Conceptual Development in Neo-Confucianism}

The Neo-Confucian philosopher Cheng Yi 程頣 (1033-1107) highlighted the following crucial notion in Neo-Confucianism: “' 'Essence' and 'function' originate from one and the same root, and manifestation and latency do not interfere with each other.” ${ }^{24}$ According to Yisue 易 學, the universe can be explained through trigrams ( $g u a$ 卦), the symbols used to represent the fundamental 'principle' of reality. In dialectical terms, trigrams reveal 'principle,' which is already latent in the trigrams; and as a corollary, these trigrams can be identical. Cheng Yi explained the relationship between 'phenomena' and 'principle' in the following way: "Nothing is more vivid than 'phenomena' and nothing is more subtle than 'principle.' However, 'phenomena' and 'principle' are identical by nature, and they have one and the same origin. A gentleman (junzi 君 子) can thoroughly cultivate himself. This is because he is able to master both 'phenomena' and 'principle.' " 25 This is the same as saying that 'principle' is 'essence' and a 'phenomenon' is 'function.'

In his book, The Confucianism in Song and Ming, Chen argued that Cheng Yi' s conception of 'essence' and 'function' originating from one and the same root is a way of advancing Confucian philosophy. ${ }^{26}$ However, it is implausible to claim that this idea came exclusively from the Confucian tradition. This derivation is difficult to detect in most strands of ancient Chinese philosophy other than in Buddhist schools of thought like Huayan. It is clear that Cheng Yi was profoundly influenced by the Buddhism of his time.

The monistic interpretation of 'principle' and 'vital force' ( $q i$ 氣 $)^{27}$ of Cheng Hao 程影 (1032-1085), who is Cheng Yi' s brother, was also related to Buddhist thought. ${ }^{28}$ His metaphysical 'principle' and physical 'vital force' correspond, respectively, to 'unconditioned factors' (wuweifa 無爲法) and 'conditioned factors' (youweifa 有爲法), the dual concepts which are of fundamental importance in Buddhist ontology. ${ }^{29}$ The 'unconditioned factors' are those which are not subject to impermanence (wuchang 無常). The 'conditioned factors' are, on the other hand, those which are produced by causes and conditions (yinyuan 因緣). They are governed by four modes of event: arising (sheng 生), abiding ( $z h u$ 住), changing ( $y i$ 異), and ceasing (mie 滅). 'Principle' is permanent and does not change, while 'vital force' changes in accordance with conditions.

Zhu Xi 朱喜 (1130-1200) further developed the Cheng brothers' concept of 'essence-function,' based on the complementary framework of 'principle' and 'vital force.' He elaborated a taxonomy

23 Note (DHY) 2,a8-c6: 動靜一源者 法界體也....... 動靜迷悟雖有二門 所迷真性一源莫二 莫二之源即是體也........必求靜 於諸動 必求靜於諸動故 雖動而常靜則動靜名殊 其源莫二 莫二之源 即一體也....... 動即是事 靜即是理 動靜一源 即事理無 礙法界.

24 (BCY) 157,a12-13: “體用一源顯微無間.”

25 (IChY) 259,b8-9: “至顯者莫如事 至微者莫如理而事理一致 微顯一源 古之君子所以善學者以其能通於此而已”。

26 See (Chen 1997), pp. 146-47.

$27 Q i$ is translated as 'material energy,' 'life force,' or 'energy flow.' It is an element of all living entities. We employ the English term 'vital force' to designate $q i$.

28 Note (IChY) 129,b9-11: 凡物之散 其氣遂進 無復本源之理....... 其散之氣 豈有復在.

29 See (Lin 1966), pp. 11-36. 
of forms of metaphysical and physical flux in Yisue 易學. ${ }^{30}$ All things possess 'principle,' but they manifest it differently due to the different qualities of their 'vital force.' Zhu Xi argued that metaphysical 'principle' provides the basis for 'phenomena,' whereas physical entities are simply vectors of their metaphysical counterpart. ${ }^{31}$ Here, the 'principle' is 'essence' and the 'vital force' that manifests empirical things in the world is 'function.' According to Zhu Xi, 'principle' and 'vital force' are fundamentally synchronic, but in the conventional sense the former exists prior to the latter. It is assumed that things take on their form through the operation of their 'vital force' after the appropriation of 'principle.' ${ }^{32} \mathrm{Zhu} \mathrm{Xi}^{\prime}$ ' $\mathrm{s}$ 'principle' -centered proposition is supported by his assertions that 'principle' is transcendent in character; it exists independently; and it acts separately from the physical world. In this light, if we follow the logic of Zhu Xi' s thought, 'essence' is given primacy over 'function.'

\section{Concluding Remarks}

This paper has examined the concept of 'essence-function' in the context of the Buddhist and the Confucian traditions. Discussion thus far leads us the following main points:

(1) The terms 'essence' ( $t$ i) and 'function' (yong) appear already in Confucian and Daoist works such as the Xunzi and the Zhouyi cantong qi. At the same time, however, they did not constitute a hermeneutical framework for interpreting the status of things in the physical world.

(2) The paradigm of 'essence' and 'function' was first employed in a philosophical context by Wang Bi who argued that the 'function' of myriad things stems from nonexistence. This nonexistence was the predecessor of the concept of 'essence,' which was formed under the influence of the Buddhist notion of emptiness.

(3) Subsequently, this paradigm was appreciated by the Buddhists who came after Wang Bi. Sengzhao understood 'essence' and 'function' in terms of the twofold truth. From the perspective of conventional truth, 'essence' and 'function' are different. From the perspective of ultimate truth, on the other hand, they are of mutual identity (xiangji 相郎).

(4) Post-Sengzhao Buddhists discussed the reason for the mutual identity of 'essence' and 'function' in terms of the concept of 'one mind' in the Awakening of Mahyna Faith. The 'essence' and the 'function' originate from 'one mind.' They are by nature identical, but differ only in their aspect.

(5) Huayan studies further developed the idea that 'essence' and 'function' share the same origin. Fazang interpreted the dual concept in terms of the relationship between 'principle' and 'phenomena.' 'Essence' as 'principle' has the same flavor (yiwei一味) with 'function' as 'phenomena.' By employing the comparison of movement and stillness, Chengguan clarified that the world of truth embraces 'principle' and 'phenomena' as a collective whole in which they do not impede one another.

30 According to the Book of Changes, metaphysical entities constitute the Way (dao 道), and physical things are containers ( $q i$ 器). See (BC) 614,a18-20: 是故形而上者謂之道 形而下者謂之器.

31 Note (CWZh) 367,a16-18: 天地之間有理有氣 理也者形而上之道也. 生物之本也 氣也者 形而下之器也. 生物之具也. 是以人 物之生必禀此理然后有性 必禀此氣然后有形.

32 See (CSZh) 18,a3-4: 或問 必有是理 然後有是氣 如何 曰 此本無先後之可言 然必欲推其所從來 則須說先有是理. Note also (Gedalecia 1974; Kang 2000; Cua 2002). 
(6) Huayan conception of 'essence' and 'function' exerted profound influence upon Neo-Confucianism. The Cheng brothers confirmed that 'essence' and 'function' originate from one and the same root. This idea served as a basic tool for interpreting the universe in Chinese philosophy. The Cheng brothers understood the Huayan concepts of 'principle' and 'phenomena' as 'principle' and 'vital force.' 'Principle' corresponds to the 'essence' that is permanent and does not change; 'vital force' corresponds to the 'function' that changes in accordance with conditions.

(7) Zhu Xi focused on illustrating the status of 'essence' and 'function' through the framework of 'principle' and 'vital force.' While accepting that 'essence' and 'function' originate from one and the same root, he held an 'essence' -centered position. Zhu Xi emphasized the priority of 'essence' over 'function'.

Author Contributions: S.-h.K. and J.W. worked together for this article.

Funding: This work was supported by the Academy of Korean Studies (KSPS) Grant funded by the Korean Government (MOE) (AKS-2012-AAZ-2102).

Conflicts of Interest: The authors declare no conflict of interest.

\section{References}

\section{Primary Sources}

(AMF) The Awakening of Mahyna Faith 大乘起信論. In T. No. 1666, 32.

(BC) The Book of Changes 周易. 1973. Seoul: The Institute for Korean Theology.

(BCY) The Book of Change by Yi Chuan 伊川易傳. In WS 9.

(CLD) Commentary on the Laozi Daode jing 老子道德經注. In WS 1055.

(CSZh) Classified Sayings of Zhu Xi 朱子語類. In WS 700.

(CWZh) Collected Works of Zhu Xi 朱子集. 1984. Seoul: Bokyoung Munhwasa.

(DH) Dafangguangfo Huayanjing Shu 大方廣佛華嚴經疏. In T. No. 1735, 35.

(DHY) Dafangguangfo Huayanjing Suishu Yanyi Chao 大方廣佛華嚴經隨疏演義鈔. In T. No. 1736, 36.

(DJ) Dahuayan Jing Lue 大華嚴經略. In T. No. 1737, 36.

(DZ) Dao zang 道藏. 1994. Shanghai: Shanghai Book Company.

(HY) Huayan Jing Yihaibai Men 華嚴經義海百門. In T. No. 1875, 45.

(IChY) Er Cheng Yishu二程遺書. In WS 698.

(T) Taisho tripitaka 大正藏.

(WS). Wenyuange Siku Quanshu 文淵閣四庫全書. Taipei: Taiwan shangwu yinshuguan 臺灣商務印書館, 2013.

(Xunzi) Xunzi 苗子. Hong Kong: The Chinese University of Hong Kong Institute of Chinese Studies and the Commercial Press, 1996.

(ZhL) Zhao lun 肇論. In T. No. 1858, 45.

(ZhS) Zhouyi Cantongqi Shang 周易參同契上. In DZ 20.

\section{Secondary Sources}

Chen, Lai. 1997. The Confucianism in Song and Ming. Seoul: Yemun Book Company.

Cook, Francis. 1997. Huayen Buddhism: The Jewel Net of Indra. University Park: Pennsylvania State University Press.

Cua, Antonio S. 2002. On the Ethical Significance of ti-yong Distinction. Journal of Chinese Philosophy 29: 163-70. [CrossRef]

Garfield, Jay. 2002. Empty Words: Buddhist Philosophy and Cross-Cultural Interpretation. Oxford: Oxford University Press.

Gedalecia, David. 1974. Excursion in Essence and Function: The Development of the $t$ ' $i$-yung Paradigm in Chu His. Philosophy East and West 24: 443-51. [CrossRef] 
Hamar, Imre. 1998. Chengguan's Theory of the Four Dharma-Dhtus. Acta Orientalia Academiae Scientiarum Hungaricae 51: 1-19.

Kang, Jinsuk. 2000. The Study of Zhu Xi's ti-yong. Ph.D. dissertation, Beijing University, Beijing, China.

Knoblock, John. 1988. Xunzi: A Translation and Study of the Complete Works. Stanford: Stanford University Press, vol. 2.

Lim, Chaewoo. 1997. The Study of the Influence of Buddhism in Han and Wei Dynasty on Wang Bi's Daoism. The Study of Religion 13: 113-32.

Lin, Ketang. 1966. Song Confuciainist and Buddhism. Taibei: Taiwan Sangwu Press.

Lu, Cheng. 1979. The Study of Origin in Chinese Buddhism. Sanghai: Zhonghua Book Company.

Lu, Cheng. 1996. The Brief Lecture about Origin of Chinese Buddhism. Shandong: Qilu Book Company.

Mair, Victor. 2012. What is Geyi, After All? China Report 48: 29-59. [CrossRef]

Muller, Charles. 1999. Essence-Function ( $t$ ' i-yung): Early Chinese Origins and Manifestations. Bulletin of Toyo Gakuen University 7: 93-106.

Muller, Charles. 2016. The Emergence of Essence-Function (ti-yong) 體用 Hermeneutics in the Sinification of Indic Buddhism: An Overview. Bulgyohak Ribyu 19: 111-52.

Park, Sung-bae. 1983. Buddhist Faith and Sudden Enlightenment. New York: Suny Press.

Ryden, Edmund. 2002. Zhang, Dainian's Key Concepts in Chinese Philosophy. New Haven: Yale University Press.

Tang, Yongtong. 2002. Hanwei Laingjin Nanbeichao Fojiaoshi 漢魏兩晉南北朝佛教史. Shijiazhuang: Renmin Book Company.

Wang, Xiaoyi. 1993. The Study of Relationship of Buddhism and Heyan in Han and Wei. Zhonghua Foxue Xuebao 中華佛學學報 6: 207-17.

Zhang, Dainian. 1996. The Rule of Chinese Ancient Ontological Development. Shijiazhuang: Renmin Book Company.

(C) 2019 by the authors. Licensee MDPI, Basel, Switzerland. This article is an open access article distributed under the terms and conditions of the Creative Commons Attribution (CC BY) license (http://creativecommons.org/licenses/by/4.0/). 